\title{
Antioxidant Activity of Bacterial Cellulose Based Edible Films Incorporated with Catechin and Citrus aurantium L (Bergamot) Essential Oil
}

\author{
Yoice Srikandace ${ }^{1 *}$, Sylviana $^{2}$, Nina Artanti ${ }^{3}$, Zalinar Udin $^{3}$ and M.Hanafi ${ }^{3}$ \\ ${ }^{1}$ Indonesian Institute of Sciences-Research Unit for Clean Technology, \\ Jl. Cisitu-Sangkuriang Bandung, Indonesia. \\ ${ }^{2}$ Departement of Nutrition and Food Technology, Faculty of Life Sciences, Surya University \\ SETOS Building, Jl. M.H. Thamrin Km. 2.7, Tanggerang, Indonesia \\ ${ }^{3}$ Indonesian Institute of Sciences-Research Centeer for Chemistry, \\ Jl. Kw.Puspiptek, Muncul-Serpong, Tanggerang, Indonesia \\ *E-mail: yoice.srikandace.s@gmail.com
}

\begin{abstract}
Bacterial cellulose-based edible films have been known as natural material and eco-friendly fibers for food packaging. The edible films contain carboxymethyl cellulose (CMC), Tween 80 and glycerol as an external food protection. The edible films as carriers of ingredients agents (antimicrobial, antioxidant) preserve the quality of food product. Incorporating antioxidant compounds into edible films provide the novel approach to improve the safety, shelf-life of foods and physical properties. In present study, the antioxidant agents are cathechin and bergamot oil. The study was aimed to investigate the antioxidant activities of edible films incorporated with catechin (FC), bergamot oil (FB) and both cathechin and bergamot oil (FCB). Antioxidant activity was carried out using DPPH method. The results showed that antioxidant activities of FC, FB and FCB with various concentrations antioxidant agents (1-2.5\%) were $65.78 \%, 73.16 \%$ and $81.07 \%$ respectively. GC-MS showed bergamot oil contained compounds limonene $(23,66 \%)$, linalool (19.44), and lynalil acetate $(37,88)$. SEM showed the surface of edible films FB and FCB were fine and smooth. Edible film only and FC revealed the cracks on the surfaces of films. Alll compounds of edible films were still available based on FTIR results.
\end{abstract}

Key words: Bacterial cellulose, Bergamot oil, Catechin, Edible film, Packaging

\section{INTRODUCTION}

Bacterial cellulose (biocellulose) is pure extracellular fiber produced by Acetobacter spp that has numerous applications in food, biomedical and paper industries [1]. Biocellulose was produced by Gluconacetobacter xylinum (formerly Acetobacter xylinum) using coconut water and it is popularly known as nata-de-coco [2][3]. In general, the production of nata de coco is done by direct inoculation into liquid medium. The average time for producing nata was 11 days, with an average thickness of $0.8 \mathrm{~cm}$ [3]. Bacterial cellulose fibers exhibited the very pure fiber, very stiffness, strenght, high termal stability and similar to plant cellulose [4][5]. It also displays unique properties including high tensile strength, high water absorption capacity, high crystallinity and an ultra-fine[4]. Nowadays, bacterial cellulose also provides biodegradable material package in order to reduce the use of synthetic materials that contribute to environmental contamination [6][7]. The biocellulose is biodegradable biopolymer for friendly packaging, especially food protection. The usage of biocelulose as packaging has been limited due to the poor mechanical and barrier properties [6]. Biocellulose can perform as edible films for packaging food product and as carriers of foods additives such as antioxidant or antimicrobial agent to improve the characteristic of the edible films [8][9][10]. Edible films of biocellulose as food packaging containing antioxidants like catechin combined with bergamot essential oil can create a novel alternative to reduce oxidation in food products. The essential oils and catechin can demonstrate their ability in inhibiting free radical to increase food products with higher quality and safety. Previous study showed that methanol and water extract of Citrus aurantium $\mathrm{L}$ fruit revealed the antioxidant components. The total phenol content of the extracts ranged from 2.5 to $22.5 \mathrm{mg} / \mathrm{g}$ and 5.0 to $45.0 \mathrm{mg} / \mathrm{g}$ of pulp and peel fragments respectively

Corresponding Author: Yoice Srikandace, Indonesian Institute of Sciences-Research Unit for Clean Technology, Jl. CisituSangkuriang Bandung, Indonesia, yoice.srikandace.s@gmail.com 
[11]. The major constituents of the different parts of $C$. aurantium L. essential oils were: $\beta$-pinene $(0.62 \%-$ $19.08 \%)$, limonene $(0.53 \%-94.67 \%)$, trans- $\beta$-ocimene $(3.11 \%-6.06 \%)$, linalool $(0.76 \%-58.21 \%)$, and $\alpha-$ terpineol $(0.13 \%-12.89 \%)$ [12][13][14]. The essential oils from leaves, flowers, fruits and peel of Citrus aurantium, Citrus limetta and Citrus limon served as the potential source of natural antioxidants [12][13][15]. The plants also produce secondary metabolite that perform antioxidant properties such as catechin [16]. Catechin is the natural phenol that belongs to flavonoid compound [17][18]. The total phenolic and total tannin contents of commercial black catechu and green tea, yellow tea, and black tea showed high antioxidant activities about $63.68-75.51 \%$ with $\mathrm{IC}_{50}$ 3.92$3.31 \mathrm{mg} / \mathrm{mL}$ [16][19]. The effectiveness edible film incorporated with catechin and essential oil is limited. There is no data that biocellulose incorporated with bergamot oil and catechin is studied. Therefore, the objectives of present study are to investigate antioxidant activity from edible films and to analysis the mechanical properties of edible film.

\section{EXPERIMENT}

\section{Materials and preparation of bacterial cellulose- based edible film}

Bergamot essential oil were purchased from Lansida Group. Nata de coco gels were purchased from local industry in Cianjur, West Java Province, Indonesia. Gels were washed and boiled with water containing $\mathrm{NaOH}$ $0.5 \%$ until the gels were stable on $\mathrm{pH} 7$. A total of $0.5 \mathrm{~kg}$ gel was blended with $200 \mathrm{~mL}$ water in order to obtain the slurry of biocellulose

\section{Preparation of bacterial cellulose composites}

An amount of $100 \mathrm{~mL}$ slurry was added with $1.0 \%$ carboxymethyl cellulose (CMC), $200 \mu \mathrm{L}$ glycerol, $0.1 \%$ Tween 80 and $0.5-2.5 \%$ essensial oil and 0.005 of catechin. All composites was mixed in a beaker glass under magnetic stirring condition at $70^{\circ} \mathrm{C}$, then poured on the trays. The trays were held overnight at $45^{\circ} \mathrm{C}$ in oven blower, then cooled at room temperature before peeling the films off the trays and stored in plastic bags until used.

\section{Antioxidant assay}

A total of $0.5 \mathrm{~g}$ of edible film was extracted with methanol for $1 \times 24 \mathrm{~h}$ to obtain methanol extract. For the evaluation, $2.0 \mathrm{~mL}$ of $0.1 \mathrm{mM}$ DPPH solution was added with $1.0 \mathrm{~mL}$ of sample in a test tube, shaken and incubated in dark room for 30 minutes. Then, samples were read using a spectrophotometer at $517 \mathrm{~nm}$. The antioxidant activity was calculated as percentage inhibition of DPPH, using the following equation: \%inhibition $=($ Ao-As $) /$ Ao $\times 100 \%$

Ao is the absorbance of DPPH and As is the absorbance of sample.

\section{Mechanical propeties}

The mechanical properties of edible films were characterized by Orientec UCT-5T universal testing with $100 \mathrm{kgf}$ load cell according to ISO 527- 1993E standard method. Dumbbell-shaped specimens were obtained from each film according to ISO 527-2 type $5 \mathrm{~A}$. The measurement was conducted at temperature of $23^{\circ} \mathrm{C}$ and relative humidity of $50 \%$. At least five specimens of each sample was measured and computerized calculated to obtain the average value.

\section{FourierTransform Infra Red (FTIR) analysis}

Fourier-transform infrared (FTIR) spectroscopy was conducted with Thermo Scientific Nicolet iS5 Spectrophotometer using the potassium bromide disk technique, in the range of $4000-500 \mathrm{~cm}^{-1}$ with an attenuated reflectance (ATR).

\section{Scanning Electron Microscope (SEM) analysis}

Edible films were examined for surface characteristics using SEM JEOL JSM IT-300 JAPAN operating at $20 \mathrm{kV}$. Film pieces were mounted on aluminum stubs using double-sided tape and then coated with a layer of gold (40-50 $\mathrm{nm})$, allowed surface and cross-section visualization.

Gas chromatography mass spectrometry (GC-MS) analysis

The bergamot essential oil was analyzed using the Agilent 7890 B with MSD 5977A. One microliter of diluted sample (1/100 in methanol, v/v) was injected manually (split mode, split ratio 1:20). Calculation of peak area percentage was performed on basis of the FID signal using the GC HP-Chemstation software.

\section{RESULT AND DISCUSSION}

All edible films containing catechin (FC), Bergamot oil (FB), catehin and Bergamot oil (FCB) showed antioxidant activity and desribed in Table 1. Based on Table 1, the edible FC inhibited DPPH about 55.58$65.78 \%$ with $0.04-0.05 \%$ catechin concentrations. The film FB revealed percentage inhibition 67.08-73.16\% with $2-2.5 \%$ bergamot oil. The edible FCB also presented percentage inhibition range in 50.17-81.07\% with $1.0-2.5 \%$ oil concentrations as the best activity. Catechin has been known widely as antioxidant properties that isolated from tea plants. The peels of bergamot oil and Citrus spp produce aromatic and volatile compouds that perfom antimicrobial and antioxidant activity. The combination of catechin and 
bergamot oil increased inhibition rate against DPPH. It also indicated that the compounds were stable for edible films.

Table 1. Antioxidant activity of the edible films

\begin{tabular}{|c|c|c|}
\hline Sample & Composite additives & Inhibition (\%) \\
\hline \multirow[t]{5}{*}{ FC } & $0.01 \%$ catechin & 21.19 \\
\hline & $0.02 \%$ catechin & 34.39 \\
\hline & $0.03 \%$ catechin & 43.35 \\
\hline & $0.04 \%$ catechin & 55.58 \\
\hline & $0.05 \%$ catechin & 65.78 \\
\hline \multirow[t]{5}{*}{ FB } & $0.5 \%$ oil & 13.99 \\
\hline & $1.0 \%$ oil & 33.13 \\
\hline & $1.5 \%$ oil & 46.69 \\
\hline & $2.0 \%$ oil & 67.08 \\
\hline & $2.5 \%$ oil & 73.16 \\
\hline \multirow[t]{5}{*}{ FCB } & $\begin{array}{l}0.05 \% \text { catechin }+ \\
0.5 \% \text { oil }\end{array}$ & 35.89 \\
\hline & $\begin{array}{l}0.05 \% \text { catechin }+ \\
1.0 \% \text { oil }\end{array}$ & 50.17 \\
\hline & $\begin{array}{l}0.05 \% \text { catechin }+ \\
1.5 \% \text { oil }\end{array}$ & 62.45 \\
\hline & $\begin{array}{l}0.05 \% \text { catechin }+ \\
2.0 \% \text { oil }\end{array}$ & 77.11 \\
\hline & $\begin{array}{l}0.05 \% \text { catechin }+ \\
2.5 \% \text { oil }\end{array}$ & 81.07 \\
\hline
\end{tabular}

Some studies showed the black catechu plants were rich source for catechin with percentage of free radical scavenging varied from $2.62-75.47 \%$ in black catechu and $74.18-77.06 \%$ in white catechu [16]. The Sichuan tea (green tea, yellow tea, and black tea) described the scavenging rate of hydroxyl radicals about 54.18 $75.51 \%$ [19]. The study of Citrus sinensis and C.aurantium showed the antiradical activity varies from $58.48-92.55 \%$ (leaves) and $55.46-88 \%$ (peels) [13][20][21].

Mechanical properties of all edible film were analyzed for tensile strength (TS) and elongation break (EB). The properties was described in Table 2.

Table 2. Mechanical properties of edible films

\begin{tabular}{|l|c|c|}
\hline Sample & $\begin{array}{c}\text { Tensile strength } \\
(\mathrm{Mpa})\end{array}$ & $\begin{array}{c}\text { Elongation } \\
(\%)\end{array}$ \\
\hline Edible film A & 62.72 & 20.00 \\
FC & 62.97 & 20.11 \\
FB & 58.12 & 22.50 \\
FCB & 58.27 & 22.31 \\
\hline
\end{tabular}

Edible film A : film contained all composites (CMC, gliserol and Tween 80)

Table 2. showed the edible film A obtained 62.72Mpa (TS) and 20\% (EB). The edible FC performed TS (62.97 Mpa) and EB (20.11\%) did not show a significant diffrent value of TS andEB from edible film A. On the other side, edible films were enriched with bergamot oil (FB and FCB) decreased the TS value but increased the EB. The tensile strenght of FB and FCB decreased from 67.72 Mpa to 58.12-58.27 Mpa. Elongation of FB and FCB increased from $20.00 \%$ to $22.50-22.31 \%$. The change of TS and EB value was due to interactions CMC and glycerol (polymer chains) with oil. The CMC, glycerol and oil filled, interfered the matrix of films and produced solid fine films. Glycerol also performed as plasticizer and demonstrated higher moisture content for biodegradable films [22]. The study of edible films with various concentrations of $\mathrm{CMC}$, glycerol and some citrus oils showed range TS value 66-180 Mpa andEB value $22.9-11.8 \%$ as well[23][24]. It proved that CMC, glycerol and oils decreased the tensile forces but increased the elongation break.

The FTIR analysis (figure 1, figure 2, figure 3 and figure 4) described the characteristic bands of all films with addition of CMC, glycerol, catechin and oil.

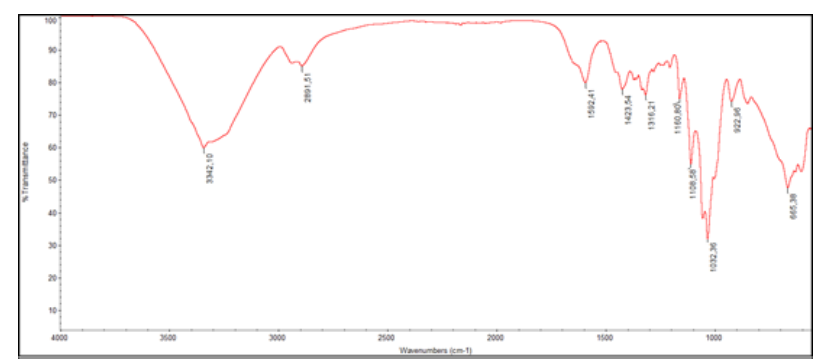

Fig 1 The FTIR spectra of biocellulose ,CMC and glycerol composite edible film.

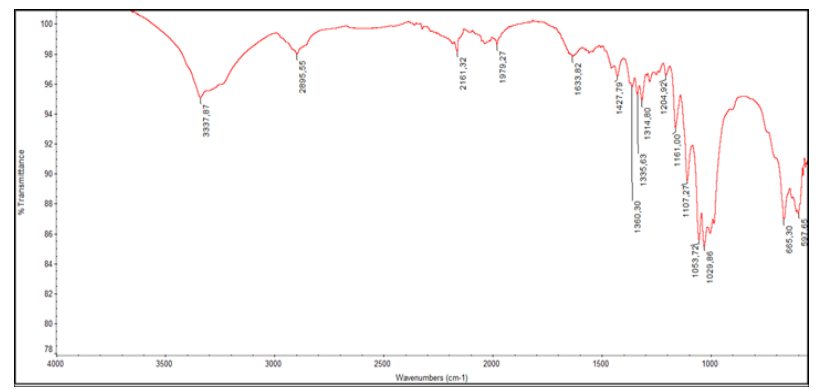

Fig 2 The FTIR spectra of biocellulose ,CMC, glycerol and catechin composite edible film.

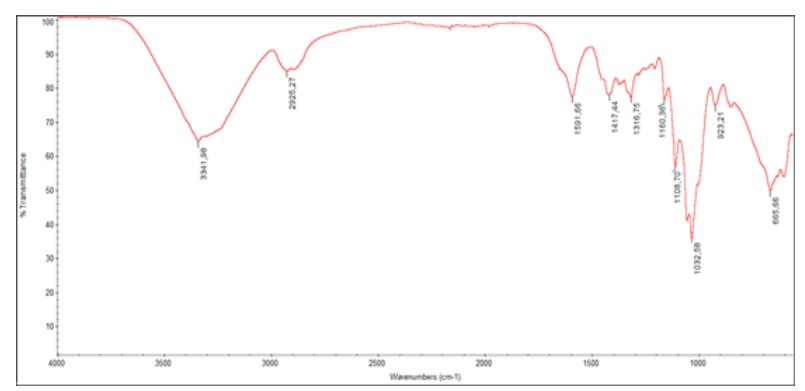

Fig 3 The FTIR spectra of biocellulose ,CMC, glycerol, catechin and $2 \%$ Bergamot oil composite edible film. 


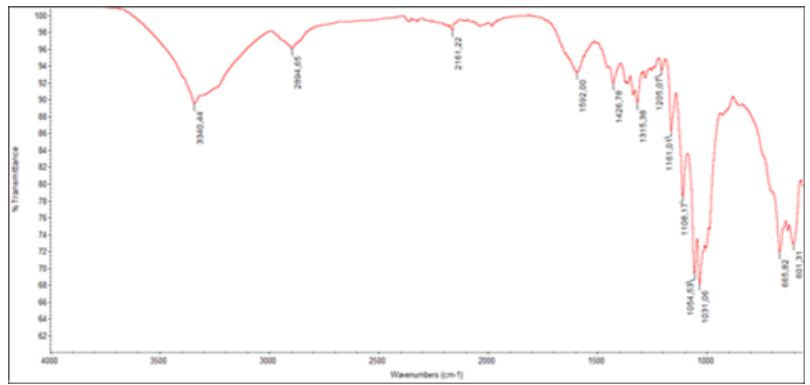

Fig 4 The FTIR spectra of biocellulose ,CMC, glycerol, catechin and $2 \%$ Bergamot oil composite edible film FBC

Based FTIR spectras, all films showed $\mathrm{O}-\mathrm{H}$ group peak at $3337-3342 \mathrm{~cm}^{-1}$, performed an important role in the physical properties of films. Peak at 2894-2925 $\mathrm{cm}^{-1}$ indicated the presence C-H group. The COO- of CMC were obtained peak at $1592-1533 \mathrm{~cm}^{-1}$. All spectra confirmed that the important bonds in cellulose polymer were present in the films even though the peaks and curves may change. Distinguish peaks of $3337-3342$ $\mathrm{cm}^{-1}$ that should around $3400 \mathrm{~cm}^{-1}$ to $3500 \mathrm{~cm}^{-1}$ can be associated to the hydroxyl bonds of cellulose. The spectra region can be referred to as the intermolecular and intermolecular hydrogen bonds of cellulose [25][26].

Based the SEM analysis, edible film A (Fig 5) and FC (Fig 6) showed the surface of the films obtained cracks, roughness and many pores in the films because of the large molecule size of biocellulose. Composites were not dissolved with homogenous. The appearance of films containing bergamot oil (Fig. 7) and catechinbergamot oil (Fig. 8) obtained the fibers more solid, smooth and homogenous. It was due to addition of essential oil. There was no remarkable structural difference between FB and FCB, so that Bergamot oil improved the flexibility and prevented cracks. Similar study, SEM analysis showed the surface microstructural of the edible film from breadfruit starch incorporated with essential oil of attarasa leaves was more rough and solid compared with film without incorporation of essential oils [27].

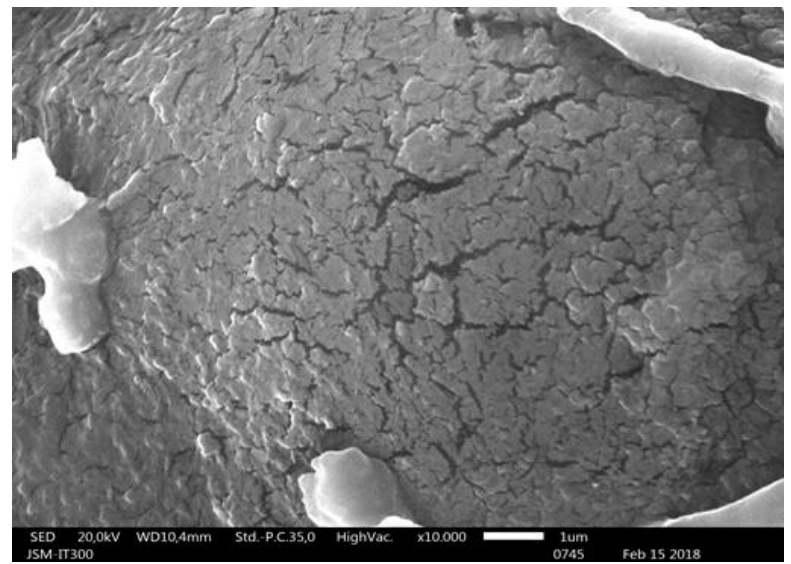

Fig 5 SEM micrographs of the surface of edible film A

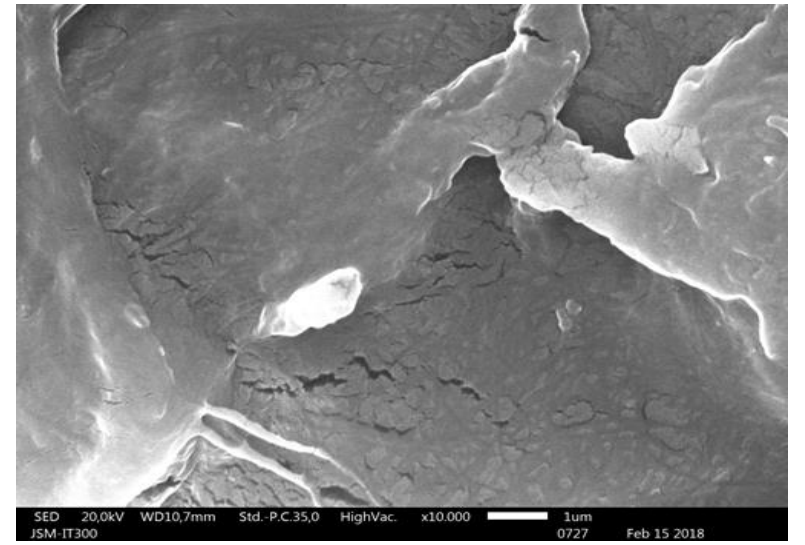

Fig 6 SEM micrographs of the surface of film FC

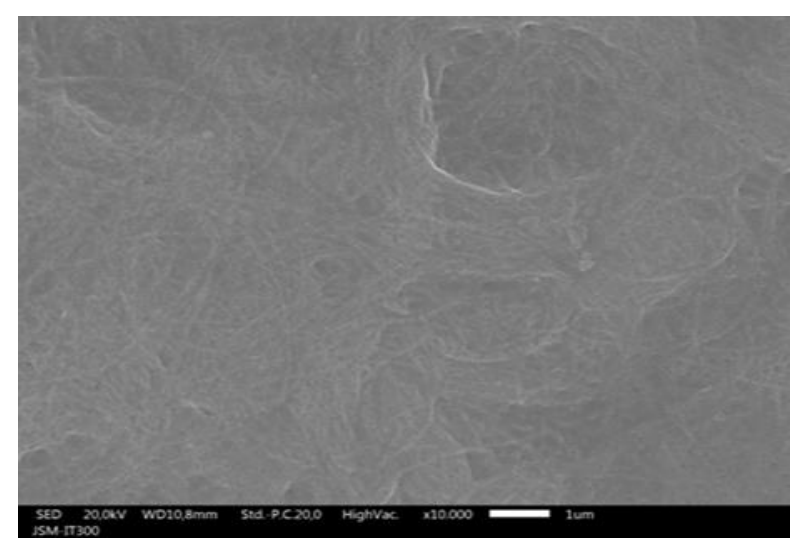

Fig 7 SEM micrographs of the surface of film FB

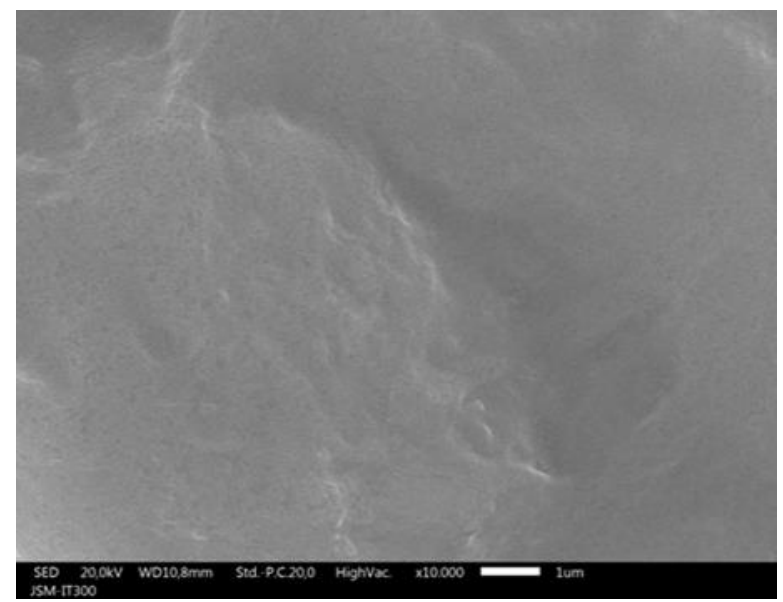

Fig 8 SEM micrographs of the surface of film FBC

The GCMS analysis results indicated the compounds of bergamot oil and described in Table 3 and Fig 9. Figure 9 and Table 3. showed bergamot oil contained 22 components accounting approximately $98.72 \%$ of the total bergamot oil contents. 


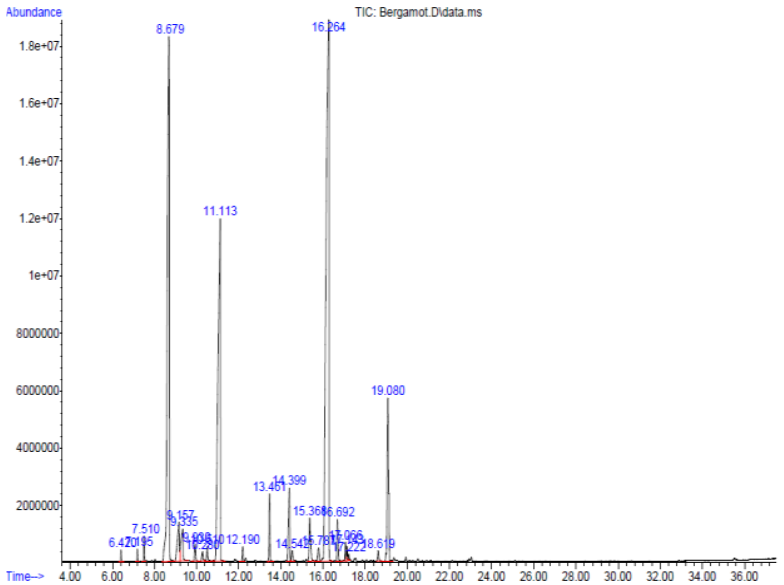

Fig 9 GC-MS analysis of volatile organic compounds of

Citrus aurantium

The composition varied considerably, depending on the geographical origin but it also contained the typically compounds such as limonene, linalool and linalyl. Limonene is the principal component of citrus spp oils (lime, lemon, sweet orange, and tangerine oils). A study revealed that the vacuum distillation of bergamot peels furnished a high-quality components of essential oil such as monoterpenes myrcene, linalool, and linalyl acetate [28]. The peels of Citrus medica L, C. junos, $C$. limon and $C$. aurantifolia contained the spesific component such as campene, citral and limonene [28][29].

Table 3 Composition of Bergamot oil

\begin{tabular}{|l|l|}
\hline Compounds & Content (\%) \\
\hline$\alpha$-pinene & 0.16 \\
$\beta$-phellandrene & 0.19 \\
$\beta$-myrcene & 0.38 \\
Limonene & 23.66 \\
2-Furanmethanol & 0.40 \\
Trans-linalool oxide (furanoid) & 0.41 \\
Linalool & 19.44 \\
Citral & 1.01 \\
Neral & 0.47 \\
Chloroacetic acid & 1.44 \\
$\alpha$-terpineol & 2.35 \\
2,6-Octadien-1-ol & 1.57 \\
Linalyl acetate & 37.88 \\
$\alpha$-Terpinyl acetate & 5.31 \\
Acetic acid & 0.12 \\
Cyclohexene & 1.24 \\
Pentafluoropropionate & 0.25 \\
Bornyl acetate & 0.12 \\
1,3-Cyclohexadiene & 0.27 \\
Cyclohexanol & 0.30 \\
3,5,5-Trimethylhexyl acetate & 1.44 \\
1,2-Dihydrolinalool & 0.30 \\
\hline
\end{tabular}

Citrus fruits have been a commercially important crop for thousands of years. Citrus essential oils are well known valuable in their flavor and fragrance properties, as well as numerous aromatherapeutic and medicinal applications. The essential oils will undoubtedly continue to play important roles in the food and beverage industries, especially for natural packaging.

\section{CONCLUSION}

Addition of catechin and bergamot oils into biocellulose based films showed an effect on mechanical properties. The film that contained bergamot oil presented the smooth surface compared to others and could enhance films' flexibility. The combination $0.05 \%$ of catechin and $1-2.5 \%$ of bergamot oil showed the antioxidant activity with range inhibition 50.17-81.07\%.

\section{ACKNOWLEDGMENTS}

The authors acknowledge the financial support from INSINAS-LIPI, Indonesia.

\section{REFERENCES}

[1] Alejandra, M.A.G., Sonia, H.C., Roberto, P.T.K. and Hafiz, M.N.I. 2016. Bacterial cellulose: A sustainable source to develop value-added productsA review. Bioresources 11, 1-15.

[2] Gayathry, G. 2015. Production of Nata de Coco - a natural dietary fibre product from mature coconut water using Gluconacetobacter xylinum (sju-1). Intl. J. Food. Ferment. Technol 5, 231-235.

[3] Darmawan, A.N. and Pradipta, A. 2015. Characterization of Nata de Coco Produced by Fermentation of Immobilized Acetobacter xylinum. Agriculture and Agricultural Science Procedia 3, $278-282$.

[4] Ali, A. and Nooshin, M.S. 2013. Bacterial Cellulose as High Performance Nano Biopolymer. Research Journal of Pharmaceutical, Biological and Chemical Sciences 5, 1324-1334.

[5] Faezah, E., Norliza, A.R., Sahaid, M.K. and Siti, M.T. 2017. Effect of agitation conditions on bacterial cellulose production by Acetobacter xylinum 01416 in fermentation of matured coconut water medium. Malaysian Journal of Analytical Sciences 21, 261-266.

[6] Ana R.V.F., Vítor D.A. and Isabel M.C. 2016. Review: Polysaccharide-based membrane in food packaging applications. Membranes 6, 1-17.

[7] Henriette M.C.A., Morsyleide, F.R. and Luiz H.C.M. 2016. Nanocellulose in bio-based food packaging applications. Industrial Crops and Products 1, 1-8.

[8] Véronique C. 2013. Polysacharide-based biomaterials with antimicrobial and antioxidant properties. Polimeros 23, 287-297. 
[9] Bhanu, M., Anu, K. and Harsha, K. 2015. Antimicrobial food packaging: potential and pitfalls. Frontiers in microbiology 6, 1-9.

[10] Reyhan, I. and Ozlem, K.E. 2015. Novel food packaging systems with natural antimicrobial agents. J Food Sci Technol 52, 6095-6111.

[11] Prakash, J.Divya., Prakash, J. and Lakshmi A.J. 2016. Antioxidant properties of fresh and processes Citrus aurantium fruit. Cogent Food \& Agriculture 2, 1-12.

[12] Eirini, S., Paschalina C., Kortessa, D.T. and Ioannis, T. 2013. Volatile constituents and antioxidant activity of peels, flowers and leaf oils Citrus aurantium L growing in greece. Molecules 18, 10639-10647.

[13] Majnooni, M., Kamran, M., Gholivand, M., Ali, M., Hamid, R.M.M., Afnanzade, N., Abolghasemi, M. and Marzieh, P. 2015. Chemical composition, cytotoxicity, antioxidant activities of essential oil from the leaves of Citrus aurantium L. African Journal of Biotechnology 11, 498-503.

[14] Djamel, D. 2015. Chemical profile, antibacterial and antioxidant activity of Algerian citrus essensial oils and their application in Sardina pilchardus. Foods 4, 208-228.

[15]Muthiah, P.L., Umamaheswari, M., and Asokkumar, K. 2012. In vitro antioxidant activities of leaves, fruits and peel extracts of citrus. International Journal of Phytopharmacy 2, 13-20.

[16] Thidarat, D., Chanida, P. and Nijsiri, R. 2014. Catechin and epicatechin contents and antioxidant activity of commercial black catechu and pale catechu. Journal of Chemical and Pharmaceutical Research 6, 2225-2232.

[17]Michalina, G., Katarzyna, N., Grzegorz, B. And Isabella, S. 2017. Antioxidant properties of catechins: comparison with other antioxidants. Food chemistry 1, 1-49.

[18]Jurga, B. and Dalia M.K. 2018. The role of catechins in cellular responses to oxidative stress. Molecules 23, 1-11.

[19]Jianhua, L., Shengxiang, C., Mingzhu, Z. and Xueli, M. 2017. Comparison of catechins and antioxidant activity in four kinds of Shicuan tea. IOP Conf. Series: Earth and Environmental Science 94, 1-6.

[20] Samira, L.and Khodir, M. 2013. Phenolic contents and antioxidant activity of orange varieties(Citrus sinensis L. and Citrus aurantium L.) cultivated in Algeria:Peels and leaves. Industrial Crops and Products 50, 723-730.

[21] Mila R., Antonija, P. and Franko, B. 2018. Chemical Composition and Antioxidant Activity of Essential Oil Obtained from Bitter Orange Peel (Citrus aurantium L.) Using Two Methods. Croat. Chem. Acta 91, 125-128.

[22] Sanyang, M.L., Sapuan, S.M., Jawaid, M., Ishak, M.R. and Sahari, J. 2009. Effect of plasticizer type and concentration on physical properties on biodegradable films based on sugar palm (Arenga pinnata) starch for food packaging. J Food Sci Technol 53, 326-336.

[23] Lucia, I., Indriyati, Anung, S. and Sri, P. 2016. Physical and mechanical properties of modified bacterial cellulose composite films. AIP Conference Proceedings 1711, 1-5.

[24]Lucia, I. and Indriyati. 2017. Incorporation citrus essential oils into bacterial cellulose based edible films and assement for their physical properties. IOP.Conf.Series: Earth and Envronmental Sciences 60, 1-5.

[25] Adebayo, B.C., Akintunde, M.O. and Alao, S.O. 2017. Comparative Effect of Agrowastes on Bacterial Cellulose Production by Acinetobacter sp. BAN1 and Acetobacter pasteurianus PW1. Turkish Journal of Agriculture and Natural Sciences 4, 145-154.

[26] Emilia, L.B., Concetta, C., Maria, L.D., Antonella, L., Angelo, L., Francessa, P., Carlo S. and Maria, C.V. 2008. Comparison of the volatile constituents in cold-press og Bergamot oil and a volatile oil isolated by vacuum destilation. J. Agric. Food Chem. 55, 7847-7851.

[27] Cut, F.Z., Jamaran, K., Marpongahtun and Erman M. 2013. Effect of essential oil of Attarasa leaf (Litsea cubeba Lour.Pers) on Physico-mechanical and microstrutural properties of breadfruit starchalginate edible film. Malaysian Journal of Analytical Sciences 17, 370 - 375.

[28] Aliyah, A.H., Rante, H. and Mufidah, D.RN. 2017. GC-MS analysis and antimicrobial activity determination of Citrus medica $\mathrm{L}$ var.proper leaf from South Sulawesi against skin pathogen microorganism. IOP Conf. Series: Materials Science and Engineering 259, 1-6.

[29] Joon, H.H., Naeem, K., Nargis, J. Young, S.H., Eun, Y., Ji, Y.C., Cheong, M.L. and Kyong, S.K. 2016. Review: Determination of Volatile Flavour Profiles of Citrus spp. Fruits by SDE-GC-MS and Enantiomeric Composition of Chiral Compounds by MDGC-MS. Phytochemical analysis 1, 1-12. 